\title{
The change of the image of women in the modern world and eating disorders
}

\author{
Barbara Szyszkowska ${ }_{\text {ABCDEFG }}^{1}$, Celina Łepecka-Klusek ${ }_{\text {ABCDEFG }}^{1}$ Katarzyna Kozłowicz ${ }_{\text {ABCDEFG }}^{2}$
}

${ }^{1}$ Chair and Department of Gynecology and Gynecological Endocrinology, Medical University of Lublin, Al. Racławickie 23, 20 - 089 Lublin, Poland

${ }^{2}$ Laboratory of Cosmetology and Aesthetic Medicine, Medical University of Lublin, W. Chodźki 1, 20-093 Lublin, Poland

\section{Summary}

The image of women and canons of beauty with time have been subject to a constant change. The aim of this study was to discuss the changing image of the fair sex in the modern world and to show the impact of the socio-cultural factors in the process of body image's formation and development, which may contribute to the development of eating disorders such as anorexia, bulimia, orthorexia. Eating disorders occur mainly in the developing countries where social pressure on the cult of the body can be observed. In the contemporary culture the interaction of two parallel models can be mentioned: on the one hand, a strong emphasis on a healthy lifestyle and care for a slim figure, on the other hand, the multitude of food, which encourages over-consumption. These two contradictory messages require the modern woman to use the available goods, which may contribute to the improvement of well-being, while increasing self-control over how much and what to eat. Meeting these needs is extremely difficult, because often people, who want to reach the ideal figure created by the media, decide to change their diet, which may adversely affect both the health and the perception of one's own body. . Body image disturbance may be regarded as a characteristic feature for people with eating disorders. There is therefore a continuing need to monitor this trend in popular culture and society.

Keywords: woman, image, eating disorders, diet

\section{Introduction}

The image of the female body is a variable category. It varies according to the cultural requirements and over time. The image of the fair sex from antiquity is nothing like the present image. Historically, the woman was portrayed as a person with lush shapes which indicated health and ability to procreate. From the forties of this century the ideal of womanhood is becoming increasingly slim. [1]. The model in the fifties was about $5-8 \%$ thinner than the average woman, and now the ratio is over $20 \%$ (Serwis internetowy Modeling). This model of the woman's body is still considered perfect and has an impact on the functioning of today's women, especially those belonging to the period of adolescence [1].

Deviation from the thin body model, for example overweight or obesity, nowadays tends to be treated as a problem, both in terms of aesthetics and the creation of social barriers that make it difficult to establish relationships. Many young women believe that popularity among peers can be provided mostly by a nice and attractive appearance. Obesity is seen as a reason for embarrassment, something that should be corrected by disciplining the body, preferably imitating the patterns of female silhouettes popularized by the media. Exercise kits offer various diets; appropriate incentive schemes are available in the popular culture publications throughout the media [2].

Stress caused by the fear of weight gain facilitates bad decisions related to the quality and quantity of food intake which consequently leads to eating disorders. The most frequent are anorexia, bulimia and orthorexia.

\section{The aim of the study}

The aim of this study was to discuss the changing image of the fair sex in the modern world and to show the impact of the socio-cultural factors in the process of formation and development of the body image, which may contribute to the development of eating disorders such as anorexia, bulimia, orthorexia.

The image of women in culture and the mass media

The situation in which the contemporary women are is very complicated because in most societies the physical beauty of women is more often openly contemplated than men. The body and female sexuality is considered the most important part of a woman's functioning. The physical area of this sex is built around the appearance of a woman and the manner of response. In other words - a woman is defined by her body. It is believed that every aspect of a woman's body says something about her value [3]. The woman's appearance is usually subject to judgment and not, for example, health or ability to function efficiently. Not only agility, efficiency and the speed of movement is important, but also the shape and the weight of the body [4]. On the other hand, women are constantly encouraged by the media to unlimited consumption. This cultural message puts women in a situation of conflict between the natural biological impulses and 
social commandment to maintain the control over yourself and your body [5].

Women assimilate and abide the socio-cultural standards, mainly through the mechanism of internalization, the pressure of the media messages that is posed by the frequency with which women watch on billboards, in commercials, and newspapers a slim female silhouette and by the content of these messages, which usually combine slim figure with personal and professional success. The media by using these techniques define and determine the standards of the attractiveness of a female body. They are a powerful sociocultural medium of an ideal female figure [5]. influencing the body perception disorders. According to the U.S. study 95\% of women (among those who do not have such disorders as anorexia and bulimia) overestimate their weight by a quarter, of which $40 \%$ overestimate the size of one part of your body (cheeks, waist, hips, thighs) by at least a half [1]. Bordo's research shows that $75 \%$ of the 33,000 women surveyed said they are too thick, even though only $25 \%$ were overweight by medical standards, and $30 \%$ were underweight. Among the women with underweight $45 \%$ said they are overweight [1].

Because of the media and the popular culture the problem of the modern woman's identity takes on a new dimension. Nowadays, the knowledge of identity, consisting of the general knowledge of one's self, seems inherently incomplete because - according to Wojciszke - we are living in a kaleidoscopic world, where the social roles and identities are undergoing a constant change [6]. The contemporary identity lost its universal character, because one cannot determine one type of identity. The current reality creates situations in which different visions and images of one's own self are not only undergoing an endless exchange, but even forging an impression that one can "be any (little by little) at the same time" [7]. This phenomenon involves overlapping of different roles, played in a society, as well as - increasingly often - blurring of boundaries between different roles (gender, family, professional, social, etc.). Ideal seems to be here an example of a modern woman-a mother, who plays (or wants to play) for her daughter, not only the role of a guardian and breadwinner, but also a friend, confidante, manager, make-up artist and stylist [2]. The excessive focus on one's own body, which is strengthened by the mass culture, may also take the form of [8].

- the lack of consent to aging, which may be associated with the fear of the future and the passing time or changes to which one needs to constantly adapt;

- the efforts to improve the physical condition, which may be related to overloading the body and the desire to reach unrealistic standards;

- the denial of natural physiological processes;

- the multiplication of requirements for appearance, often more difficult to achieve;

- the addictive treatments, cosmetics, and the interference of plastic surgeries.
Focusing too much attention on the problems of one's own body and adjusting it to the culturally accepted ideal makes the initial steps associated with hygiene, beauty maintenance, and physical health become ways of life, forcing one to a daily self-creation, constantly searching for information on these topics, maintaining impeccable figure and fitness [4].

Living in a society and culture that provide one with mixed signals one comes to an obvious conclusion that the mass media cannot by itself cause disturbances in body image, but they are important risk factors for body image disturbance and in interaction with other variables (body mass index, gender, family and social life impact) can also cause abnormalities in body perception and eventually contribute to the development of eating disorders [5].

\section{The image of one's own body}

The origin of the interest in physicality dates back to the 20's of the last century and refers to the name of Paul Schilder. Schilder argued that body image perception, apart from the individual perception, is also a reflection of one's attitudes towards one's own body and one's interactions with other people $[9,10]$. Creating the image of one's body takes place under the influence and experience of the incoming information, so that it can change during one's life $[10,11,12]$. Slade [13], on the other hand, stressed the importance of attitude towards one's own body, that is, its shape, size and form. Others, however, mentioned also feelings $[9,14]$. Therefore, the body cannot only be "seen", but also "felt" [12].

Body image is the mental structure that represents the individual experience - in three areas: cognitive, emotional and behavioral - associated with the appearance of one's silhouette [15]/. The cognitive aspect of body image relates to the self-perception of the figure, i.e., thoughts, beliefs and patterns of cognitive content that one has about appearance. Emotional dimension of the body image is associated with experiencing the feelings of satisfaction or dissatisfaction with the appearance of one's body or parts thereof, and with the fear of an increase in body fat, especially in the lower parts of the body [16]. However, the behavioral aspect of the body image often includes behavior that a person takes up towards shaping (diets, pharmaceuticals and cosmetics, physical exercise, in extreme cases undergoing a plastic surgery). In terms of the cognitive perception the body image disorders can be explained by referring to the self-discrepancy theory by Higgins [17]. This theory presents two types of relationships that exist between the states of the self: the first concerns the disparity in the actual self and the ideal self, i.e. differences of the self as wishful thinking, the second describes the difference between the actual and the ought self, that is divergence of the ought self $[9,17]$. On one hand, a small discrepancy comparing the two states of the self shows similarity, on the other hand, a large discrepancy shows a contradictory (opposite) 
content of the states of the self [18]. According to Higgins [17] as a result of inconsistencies in the cognitive system there may appear some emotional states that the author divided into two groups. The first are the states named dejected-related emotions, which include: sadness, discouragement, discontent, unhappiness, pain, frustration. The second, however, referred to as agitation-related emotions include: restlessness, anxiety, fear, tension, feelings of guilt, worry. The results of the research show that a high level of divergence of the self is combined with emotional distress (including disappointment and dissatisfaction), a sense of shame, low self-esteem, as well as chronic emotional problems (depression, social phobia), in the case of abnormal eating behaviors and habits - with dissatisfaction with one's body [19] which can lead to low self-esteem, obesity and the severity of eating disorders [20].

\section{EATING DISORDERS}

In the era of the prevalence of the social and cultural patterns that promote thin or even emaciated figure and restrictive attitudes towards food, eating disorders have become a major social problem and, at the same time, an issue which clearly stimulates a growing interest on the part of clinicians, nutritionists, epidemiologists and specialists in the field of public health [21, 22]. This term refers to the person who implements the abnormal pattern of behavior manifested, among others, by the adoption of excessive or insufficient amounts of food, to the point detrimental not only to the somatic functioning of the human body, but also to one's social relationships, love life, and cognitive functioning [18]. In common opinion, eating disorders are often treated as a result of a badly applied weight loss treatment. However, there exist numerous complex factors underlying this phenomenon, among which there is also a distorted body image $[23,24,25,26]$

Women with eating disorders do not acknowledge the fact that their behavior is harmful to their health and life. They cannot adequately and objectively evaluate their problems. Their personality functions on the basis of the pathological exaggeration of the corporal self, by which they are characterized by an inadequate perception of the size and the shape of their body $[12,27,28]$. Moreover, they experience themselves and their bodies more as separate entities than a psychosomatic whole. As studies have shown discrepancies between the actual and the ideal state of the self (failure to achieve personal ideals) are associated with dissatisfaction with oneself, which in turn may result in feeling ashamed, body dissatisfaction, and the symptoms of bulimia $[29,30]$. The discrepancy between the actual and the ought self (failure to meet the requirements of other people) is more connected with guilt, personal inadequacy, and symptoms of anorexia nervosa [31].

The knowledge of the subjective experience of one's own body and the attitudes towards it, as well as the components of the image of the self/the body, and discrepancies between the states of the self can be a facilitating factor, in the therapeutic process, in confronting patients with their own body and its image. Perhaps through therapeutic work (self-knowledge of one's own body, realizing one's own body, desensitizing the anxiety associated with body image, changing the views on their body, changing destructive behaviors in the context of their own body image, recording a positive image of the body) the prevention against the reperception of the body in pejorative terms [32] will help to treat the body as an integral element of the self [33], and it will also help the treatment of eating disorders.

\section{Anorexia}

Anorexia usually begins between 13-14 and 1725 years of age, although it may also begin before puberty. The disorder is about reducing weight, well below the standards adopted in relation to age and height, while incorrect assessment of their appearance and coexistence of fear of gaining weight, which results in a drastic reduction in food intake [34].

Among the biological effects of anorexia there are: low, irregular heartbeat, and low blood pressure, hypoglycemia, hypothermia, brittle bone disease resulting from estrogen deficiency that accompanies lack of menstruation; impaired renal function, dehydration, impaired digestion (abdominal pain, constipation, feeling overfull); face fuzz, so-called "peach face" - a symptom caused by swelling of the salivary glands (ears protrude from the head, the face near the cheekbone looks wider, resulting in gaining a confirmation on the body image - when people suffering from anorexia look at their face they see a round face) [35].

Socio-cultural determinants play an important role in the development of anorexia. A characteristic feature of the contemporary culture is an excessive attention to figure expressed by fashion for healthy nutrition and caring for ones silhouette, through physical exercises and treatments [30]. Sociologists suggest that the popular culture provides a number of messages relating to eating habits, the creation and control of the body, figure and appearance [36, 37]. According to current fashion for slim figure, more and more young people are obsessed with food, the use of different diets, and weight control, e.g. by starving themselves, taking laxatives, reducing appetite, inducing vomiting, doing heavy exercise. These activities may lead to the onset of anorexia [38].

Dissatisfaction with one's own body is the most important independent risk factor of the onset of the symptoms of anorexia, which suggests that dissatisfaction with the body is primal in relation to eating disorders [39]. Patients are dissatisfied with the image of their own self, they see numerous of its shortcomings (often false) compared with other people's assessments, they are critical of themselves, often haunted by guilt and shame. In addition, patients with anorexia have 
significant difficulties in establishing relationships with peers, they are characterized by mistrust and inability to develop and maintain lasting emotional ties. This mechanism is associated with rigid, impermeable boundaries of the family system in which parents try to limit as much as possible the outside influences. This prevents girls from establishing healthy relationships with other people. Rarely they express interest in intimacy with another person, they are strongly inhibited in revealing their feelings, inaccessible and they take a competitive rather than cooperative attitude towards their peers (because of the tendency to perfectionism) [32]

\section{Bulimia}

Bulimia is typical for women about 25 years old, but more often occurs in girls 16,17 or 18 -year-old. The disorder involves recurrent episodes of binge eating [34]. During these episodes patients experience a sense of loss of control over what and how much they eat. Food is consumed very quickly and most often these are high-calorie products. After the attack for some time patients feel a sense of relief associated with a decrease in tension, from which the episode begins, and at the same time have a sense of guilt, shame and remorse because of the loss of control [40]. Bulimic episode for some people is not just a single attack of gluttony, but subsequent bouts of overeating following one another in a short period of time, which may end in few days, or even weeks. During the episodes of bulimia, as well as between them, people are preoccupied with thinking about eating and excessive weight control [40]. The consequence of the attack is to strive for rapid weight loss through induced vomiting, abuse of laxatives, diuretics, and drugs that inhibit appetite and starving oneself [34].

The effects of bulimia may be different. If a bulimic provokes vomiting there may occur: secondary hypokalemia, hypovolemia, metabolic alkalosis with hyperchloraemia, hiperaldosteronism. If a sick person causes diarrhea apart from vomiting and uses diuretics the effects are: hypokalaemia, hypokalaemic nephropathy with impaired urinary concentration, metabolic acidosis with apparently normal levels of potassium, hypochloremic alkalosis, hypomagnesemia [41]. Among the effects related to the actions of a person suffering from bulimia the most common are: diarrhea, weight loss, dehydration, swelling of the parotid glands, enlarged pancreas inflammation, erosions in the esophagus and stomach erosions back of the throat, pain in the facial nerve, hoarseness, gum disease, damage to the backs of hands, swelling of the lower extremities, shortness of breath, heart rhythm disturbances, weak pulse, low blood pressure, abdominal distension, intestinal obstruction, sudden extension of the stomach, neuropathies, psychoorganic symptoms, confusion, thirst, increased urine production, myopathy, seizures, muscle spasms and disrupted menstruation [41].

People with bulimia have a greater dependence on others, expressing, inter alia, the need for care or being controlled. As Mirucka's research on body image in bulimia nervosa has shown $[10,42]$ ill women compared with healthy women have distorted images of their body and thus disturbed the corporal self. These people are often diagnosed with borderline personality (a borderline type of an emotionally unstable personality). Borderline Personality Disorder is characterized by the appearance of a good social adjustment, chronic depression or latent hostility, a sense of pain, unstable interpersonal relationships - from an intense dependence combined with manipulation [43]. In people with bulimia, there are many impulsive behaviors, such as suicide attempts, self-mutilation, medicament abuse, alcohol, drugs, and theft. These behaviors are also characteristic to a borderline personality [44].

\section{Orthorexia}

Ortoreksja is defined as a pathological fixation on eating proper and healthy food [21]. This disease, like anorexia, has its foundation in complexes and striving to maintain the dream figure. However, the essential feature of this disorder differs from others - paradoxically - to preserve good health. Such a person is obsessed with proper preparation and storage of food. Each meal is prepared with great care and attention, often with repetitive patterns which are to ensure the safety of food intake [45]. Over time, food becomes a taboo for her, or vice versa, the main topic of conversation, the patient avoids eating in public and more specifically follows restricted times, quantity and content of meals. Carefully follows designated meal hours [46, 47, 48, 49].

Patients suffering from orthorexia are convinced that often exaggerated care about the quality of nutrition will help to them to avoid diseases and to strengthen the body. Thus they eliminate from their diet foods that they consider hard to digest or unnecessary, thereby exposing their body to fatigue, dizziness and loss of balance. Another consequence is the deterioration of mood, a sense of isolation, in women menstrual cycle disorders [40]. Doctors speculate that the reason for somatic disorders can be an emotional upset. Most likely it is a sense of lack of intimacy, loneliness or low self-esteem, because of which patients with orthorexia try to move their focus from the problems in dealing with the social environment to the diet. The patients feel they have the duty of eating carefully selected food products $[47,49]$. People with orthorexia tend to be adults. They rarely report to psychologists, rather complain about poor health, visit a doctor and are being treated for a particular ailment. Due to the fact that it is a relatively new eating disorder not yet specified the exact ratio of people suffering from this disease to the self. It is believed, however, that body image for people suffering from orthorexia is distorted and deviates from reality.

The socio-cultural patterns of how an ideal woman's silhouette should look like in the twenty-first century influence the body image disorders. Deviations in the realm of perception, the inability to properly esti- 
mate the size of one's body, awareness of the discrepancy between the physical appearance and the social canon of beauty, and in consequence experiencing the feelings of shame, fear and dissatisfaction may lead the person to take up destructive and pathological behaviors (dieting, compulsive exercise, induced vomiting) that, persisting in time, can become a risk factor for eating disorders. Therefore, it seems important to experts in the fields of nutrition, medicine and psychology, as part of their practice to incorporate the theme of the mass media impact on how a person builds one's body image, and how the person sees the mass media's role in shaping one's self-esteem as a person.

\section{References:}

1. Strzelecki W., Cybulski M., Strzelecka M., Dolczewska-Samela A. Zmiana wizerunku medialnego kobiety a zaburzenia odżywiania we współczesnym świecie. Nowiny Lekarskie. 2007, 76, 2: 173-181.

2. Ostaszewska A. Popkulturowe ramy tożsamości. Media, kultura popularna, internet jako nowe środowiska kształtowania tożsamości. Ośrodek Rozwoju Edukacji. 2008: 1-15.

3. Kaschak E. Nowa psychologia kobiety. Podejście feministyczne. Gdańskie Wydawnictwo Psychologiczne, Gdańsk. 2001: 135.

4. Marszalek L., Dycht M. Mass media i reklama a choroby cywilizacyjne: anoreksja i bulimia. Seminare. Poszukiwania naukowe. 2011, 30: 147-158.

5. Izydorczyk B., Rybicka-Klimczyk A. Środki masowego przekazu i ich rola w kształtowaniu wizerunku ciała u zróżnicowanych wiekiem życia kobiet polskich. Problemy Medycyny Rodzinnej. 2009, 11 (3): 20-32.

6. Wojciszke B. Człowiek wśród ludzi. Zarys psychologii społecznej, Wyd. Nauk Scholar, Warszawa. 2009: 136-140.

7. Melosik Z. Wychowanie obywatelskie: nowoczesność, ponowoczesność, [W]: Z. Melosik, K. Przyszczypkowski red. Wychowanie obywatelskie, Studium teoretyczne, porównawcze i empiryczne. Wyd. Edytor, Toruń-Poznań, 1998: 49.

8. Machaj A. K., Lopacka-Seczyk E. Psychologiczne i społeczne wyznaczniki postrzegania i używania własnego ciała, [W]: P. Bury, D. Czajkowska-Ziobrowska red. Edukacja bez granic - mimo barier. Wyd Wyższej Szkoły Bezpieczeństwa, Poznań, 2008: 119.

9. Wojdylo K. Skala pomiaru rozbieżności Ja (SkRAP) - konstrukcja narzędzia oraz wstępna charakterystyka psychometryczna. Now. Psychol. 2004, 4: 27-45.

10. Mirucka B. Ja-cielesne fundamentem osobowości. Polskie Forum Psychologiczne. 2003, 8 (1-2): 30-40.

11. Kowalik S. Ja-cielesne - próba nowego spojrzenia. Polskie Forum Psychologiczne. 2003, 8 (1-2): 5-29.

12. Mioduchowska A. Obraz własnego ciała a we- wnętrzna aktywność dialogowa u kobiet z zaburzeniami odżywiania. [W]: O. Gorbaniuk, B. Kostrubiec-Wojtachnio, D. Musiał, M. Wiechetek red. Studia z Psychologii w KUL, tom 18, Wyd. KUL, Lublin. 2012: 175-192.

13. Slade P. D., Brodie D. Awareness of body dimentions in anorexia nervosa: A reconceptualization based in the recent literature. Eating Disorders Review. 1994, 2: 39-46.

14. Sikora I. Ciało i zdrowie w okresie późnej adolescencji. [W]: A. Brytek-Matera red. Ciało w dobie współczesności. Wybrane zagadnienia z problematyki obrazu własnego ciała. Wyd Delfin, Warszawa. 2010: 132-148.

15. Stewart T. M, Williamson D. A. Assessment of body image disturbance. [W]: J. K. Thompson red. Handbook of eating disorders and obesity. Wiley, New York. 2003: 495-514.

16. Rybicka-Klimczyk A. Czynniki socjokulturowe a zmiany w obrazie ciała i postaw wobec odżywiania się u zróżnicowanych wiekiem życia kobiet polskich. Niepublikowana praca magisterska. Uniwersytet Śląski, Katowice. 2008.

17. Higgins T.. Self-discrepancy: A theory relating self and affect. Psychol. Review. 1987, 94 (3): 319-340.

18. Weber M., Ziolkowska B. Psychological factors as determinants of diet. [W]: J. Gawecki, W. Roszkowski red. Human Nutrition and Public Health. Tom 3. PWN, Warszawa. 2009: 195-218.

19. Bessenoff G. R. Can the media affect us? Social comparison, Self-discrepancy, and the thin ideal. Psychol. Women Q. 2006, 30: 239-251.

20. Brytek-Matera A. (Nie)świadomość doznań płynących z ciała u osób z zaburzeniami odżywiania. [W]: A. Brytek-Matera red. Ciało w dobie współczesności. Wybrane zagadnienia z problematyki obrazu własnego ciała. Wydawnictwo Delfin, Warszawa. 2010: 66-86.

21. Janas-Kozik M., Zejda J., Stochel M., Brozek G., Janas A., Jelonek I. Ortoreksja - nowe rozpoznanie? Psych. Pol. 2012, XLVI (3): 441-450.

22. Makara-Studzinska M., Zaborska A. Otyłość a obraz własnego ciała. Psychiatria Polska. 2009, XLIII (1): 109-114.

23. Albisetti V. Pułapka anoreksji. Dlaczego się choruje, jak wyzdrowieć. Wydawnictwo Jedność, Kielce. 2001.

24. Bilikiewicz A. Zespoły psychopatologiczne związane z zaburzeniami procesów fizjologicznych. [W]: A. Bilikiewicz red. Psychiatria. PZWL, Warszawa.2003: 383-389.

25. Brytek-Matera A. Obraz własnego ciała u otyłych kobiet: przyczyny i stopień niezadowolenia, związek z obniżoną samooceną i strategiami radzenia sobie ze stresem. Psych. Pol. 2010, XLIV (2): 267-275.

26. Schier K. Piękne brzydactwo. Psychologiczna problematyka obrazu ciała i jego zaburzeń. Wyd Nauk SCHOLAR, Warszawa. 2010. 
27. Oles P., Brygoła E. Świadomość dialogowa - implikacje dla zdrowia [W]: M. Górnik-Durose, J. Mateusiak red. Psychologia zdrowia: Konteksty i pogranicza . Wydawnictwo Uniwersytetu Śląskiego, Katowice. 2011: 109-121.

28. Oles P. K. Dialogowe Ja: zarys teorii, inspiracje badawcze, ciekawsze wyniki. [W]: P. K. Oleś, M. Puchalska-Wasyl red. Dialog z samym sobą. PWN, Warszawa.2011: 143-174.

29. Bak W. E. Tory Higginsa teoria rozbieżności Ja. Przegl. Psychol. 2002, 45 (1): 39-55.

30. Grogan S. Body Image. Understanding Body Dissatisfaction in Men, Women and Children. Taylor and Francis Group, London, New York: Routledge. 2008.

31. Bessenoff G. R., Snow D. Absorbing society's influence: body image self-discrepancy and internalized shame. Sex Roles. 2006. 54: 727-731.

32. Brytek-Matera A., Charzyńska E. Związek pomiędzy niezadowoleniem z ciała i zmiennymi psychospołecznymi wpółwystępującymi z zaburzeniami odżywiania. Roczniki Psychologiczne. 2009. 12 (2): 129-150.

33. Brytek-Matera A. Postawy wobec ciała a obraz samych siebie u kobiet z zaburzeniami odżywiania się. Badania na gruncie teorii rozbieżności JaEdwarda Tory Higginsa. Psych. Pol. 2011. XLV (5): 671-682.

34. Sarol-Kulka A., Kulka Z. Obraz własnego ciała a seksualność kobiet z zaburzeniami odżywiania się. Postępy Psychiatrii i Neurologii. 2005. 14 (2): 115 122.

35. Jablow M.M. Anoreksja - bulimia - otyłość. Przewodnik dla rodziców, GWP, Gdańsk. 2000: 40-52.

36. Cierpialkowska L. Oblicza współczesnych uzależnień. Wyd. Nauk. Uniwersytetu im. A. Mickiewicza, Poznań. 2007: 134-135.

37. Mroczkowska D., Ziolkowska B., Cwojdzinska A. Zaburzenia odżywiania - poradnik dla rodziców i bliskich. Wyd Naukowe Scholar, Warszawa. 2007: 18-19.

38. Kowalczuk M. Pedagogiczna diagnoza i profilaktyka zaburzeń odżywiania się u młodzieży szkolnej. Of Wyd. Impuls, Kraków. 2008: 16.

39. Preti, A., Incani, E., Camboni, M. V., Petretto, D. R., Masala, C. Prevalence of symptoms of anorexia nervosa and dissatisfaction with body image among female adolescents in Floranópolis, Santa Catarina State, Brazil. Cadernos de Saúde Pública . 2008. 24 (3): 503-512.

40. Kedra E., Pietras J. Zaburzenia odżywiania - znak naszych czasów. Probl. Hig. Epidemiol. 2011. 92 (3): 530-534.

41. Wolska M.. Zaburzenia odżywiania się w perspektywie kulturowej i społecznej [W]: B. Józefik red. Anoreksja i bulimia psychiczna. Wyd Uniwersytetu Jagiellońskiego, Kraków. 1999: 104-115.

42. Mirucka B. Kwestionariusz Ja Cielesnego (Skala
J-C). Przegląd Psychologiczny . 2005 - 48, 3: 313329.

43. Radziwillowicz W., Juniewicz M. Psychospołeczne funkcjonowanie dziewcząt $\mathrm{z}$ rozpoznaniem bulimii psychicznej. [W]: w. Radziwiłłowicz red. Psychopatologia okresu dorastania. Wybrane zagadnienia. Wyd Impuls, Kraków. 2006: 74-78.

44. Cierpialkowska L. Psychopatologia. Wyd Nauk Scholar, Warszawa. 2007: 434-435.

45. Koszowska A., Dittfeld A. Zubelewicz-Szkodzińska B. Psychologiczny aspekt odżywiania oraz wpływ wybranych substancji na zachowania i procesy myślowe. Hygeia Public Health. 2013. 48 (3): 279-284

46. Fallon S., Shearman E., Sershen H. Food reward-induced neurotransmitter changes in cognitive brain regions. Neurochemical Research. 2007. 32: 17721782.

47. Rada P., Avena N. M., Hoebel B. G. Daily bingeing on sugar repeatedly releases dopamine in the accumbens shell. Neuroscience. 2005. 134: 737-44.

48. Rogers P. J., Smit H. J. Food Craving and Food «Addiction»: A Critical Review of the Evidence From a Biopsychosocial Perspective. Pharmacology Biochemistry and Behaviour. 2000. 66: 3-14.

49. Yanovski S. Symposium: Sugar and Fat-From Genes to Culture. Sugar and Fat: Cravings and Aversions. J Nutrition. 2003. 133: 835-837. 